\title{
Two haplotypes of Capsella bursa-pastoris (Brassicaceae) in Continental Chile support multiple introduction
}

\section{Dos haplotipos de Capsella bursa-pastoris en Chile continental soportan múltiple introducción}

\author{
Sergio A. Castro ${ }^{1,2, *}$, Christian Espinosa ${ }^{1}$ \& Javier A. Figueroa ${ }^{3,4}$ \\ ${ }^{1}$ Laboratorio de Ecología y Biodiversidad Vegetal, Departamento de Biología, Universidad de Santiago de Chile. Casilla 40, \\ Correo 33, Santiago. Av. Lib. B. O’Higgins 3363, Santiago, Chile. \\ ${ }^{2}$ Centro para el Desarrollo de la Nanociencia y Nanotecnología, CEDENNA, 917-0124. Av. Lib. B. O’Higgins 3363, Santiago, \\ Chile. \\ ${ }^{3}$ Centro de Estudios Arquitectónicos, Urbanísticos y del Paisaje, Facultad de Arquitectura, Urbanismo y Paisaje, Universidad \\ Central de Chile. Avenida Santa Isabel 1186, Santiago, Chile. \\ ${ }^{4}$ ONG Entorno, Avenida Vicuña Mackenna 439-A, Santiago, Chile. \\ *sergio.castro@usach.cl
}

\begin{abstract}
Shepherd's purse (Capsella bursa-pastoris; Brassicaceae) is a global weed. In Chile, this species was introduced early during Spanish colonization, however, previous studies based on allozymes and RAPD fragments, show that populations in southernmost Chile could be related to England populations. Here, we analyze the geographical variation of three sequences of cpSSR in 286 individuals of C. bursa-pastoris (ATCP46615, ATCP66701 and ATCP31017). We collected plants from 14 populations distributed over a wide latitudinal gradient in continental Chile. Only one of the markers showed variation (ATCP31017), evidencing the presence of two haplotypes along the territory. The geographic distribution of these haplotypes support previous studies based on allozymes and RAPD fragments, suggesting that C. bursa-pastoris in continental Chile was introduced at least twice.
\end{abstract}

KEYwORDS: Biological invasions, colonization history, cpSSR, continental Chile, Shepherd purse.

\section{RESUMEN}

La bolsita de pastor (Capsella bursa-pastoris, Brassicaceae) es una maleza de distribución global. En Chile, esta especie fue introducida tempranamente durante la colonización española, sin embargo, estudios previos basados en aloenzimas y fragmentos RAPD indican que las poblaciones del extremo sur de Chile estarían emparentadas con poblaciones provenientes de Inglaterra. En el presente estudio se analizó la variación geográfica de tres secuencias de cpSSR pertenecientes a 286 individuos de C. bursa-pastoris (ATCP46615, ATCP66701 y ATCP31017). Se recolectaron plantas de 14 poblaciones distribuidas en un amplio gradiente latitudinal en Chile continental. Sólo uno de los marcadores mostró variación (ATCP31017), lo que muestra la presencia de dos haplotipos de C. bursa-pastoris en el territorio. La distribución geográfica de estos haplotipos apoya la hipótesis que plantea que C. bursa-pastoris en Chile continental fue introducida al menos en dos oportunidades.

Palabras clave: Bolsita de pastor, Chile continental, cpSSR, historia de colonización, invasiones biológicas.

\section{INTRODUCTION}

Shepherd's purse (Capsella bursa-pastoris (L.) Medik.; Brassicaceae) is one of the most widely distributed plants in the world (Randall 2002, Hintz et al. 2006). This species, whose original distribution includes Europe, Asia and Northern Africa (Hurka \& Neuffer 1997), is currently present in all continents, occupying a wide latitudinal range
(Randall 2002). C. bursa-pastoris is considered a weed in most countries where it has been introduced (Randall 2002). In Chile, this species was first noted by Gay (1845), but its introduction probably occurred long before 1800 (Gay 1845, Figueroa et al. 2004). Currently, its geographical range covers the whole latitudinal extension between 18 ${ }^{\circ} \mathrm{S}$ and $56^{\circ} \mathrm{S}$ (Matthei 1995, Castro et al. 2005, Fuentes et al. 2012), including Easter Island (Zizka 1991). In Chile, 
C. bursa-pastoris occupies ruderal habitats, roadsides, wastelands, prairies, and cultivated lands (Matthei 1995).

In spite of its ubiquity and the extension of its geographic distribution, there is scarce information about introduction of C. bursa-pastoris in Chile as well as on the processes that have determined these. Analyzing allozymes and polymorphic DNA obtained by random amplification techniques (RAPD), Neuffer et al. (1999) detected two polymorphic variants of $C$. bursa-pastoris in continental Chile. One of them is widely distributed from northern to southern Chile, corresponding to polymorphic variants from Spain (Neuffer et al. 1999), while the other is distributed locally in southernmost Chile (Patagonia and Tierra del Fuego), corresponding to polymorphic variants present in England (Neuffer et al. 1999). Thus, according to these authors the variation and polymorphic distribution patterns of C. bursa-pastoris in Chile would correspond to two routes of arrival.

In the present paper, we study the variation of three microsatellite chloroplast markers (cpSSR) for C. bursapastoris, seeking to determine haplotypes and respective geographical distributions. With these findings we discuss the colonization model proposed by Neuffer et al. (1999) for C. bursa-pastoris in Chile.

\section{MATERIALS AND METHODS}

SAMPLING

Between 2008 and 2012, specimens of the genus Capsella were collected from 14 populations distributed over a wide latitudinal range (Table I). In the field, fresh leaves were removed from each specimen and were stored in $50-\mathrm{mL}$ Falcon tubes with $20 \mathrm{~g}$ of silica gel. The tubes were labeled and stored under laboratory conditions. In the laboratory the $C$. bursa-pastoris and $C$. rubella individuals were distinguished by cloning of the trnD-trnY fragment of the cpDNA carried out by the Amplification Refractory Mutation System (ARMS; Newton et al. 1989); thus, 286 specimens of C. bursa-pastoris were recognized by ARMS-technique and whereas the $C$. rubella's specimens were excluded from the following analyses. Samples of C. bursa-pastoris were submitted to analyses of three microsatellite loci (cpSSR), amplified from cpDNA. These markers correspond to the ATCP46615, ATCP66701 and ATCP31017 loci, documented by Ceplitis et al. 2005 (Table II).

\section{GENOME EXTRACTION AND MARKER AMPLIFICATION}

A total extraction of genomic DNA was carried out using CTAB extraction buffer procedure described by Doyle \& Doyle (1990) and modified by Allen et al. (2006). Each sample was processed under the following conditions: $100 \mathrm{mg}$ of leaf tissue powdered with liquid nitrogen were incubated in $0.7 \mathrm{ml}$ of buffer [120 mM Tris-HCL pH 8.0, 80 mM EDTA pH 8.0, 0.5\% triton X-100, 0.5\% $\beta$-mercaptoethanol] for $20 \mathrm{~min}$ at $45^{\circ} \mathrm{C}$. Then, the aqueous phase was removed and the sediment was incubated in $0.7 \mathrm{ml}$ of $2 \mathrm{X}$ CTAB buffer $[2 \% \mathrm{w} / \mathrm{v}$ hexadecyltrimethylammonium bromide, $5 \mathrm{M} \mathrm{NaCl}, 2 \mathrm{M}$ Tris- $\mathrm{HCl} \mathrm{pH} 8.0,0.5 \mathrm{M}$ EDTA, $0.1 \mathrm{M}$ sodium sulfite, 1\% w/v PVP40, $0.5 \% \mathrm{v} / \mathrm{v}$ $\beta$-mercaptoethanol] at $60{ }^{\circ} \mathrm{C}$ during $20 \mathrm{~min}$, and then $5 \mu \mathrm{l}$ of proteinase $\mathrm{K} 10 \mathrm{mg} / \mathrm{ml}$ and $1 \mu \mathrm{l}$ of RNAsa A $10 \mathrm{mg} / \mathrm{ml}$

TABLE I. Localities and geographic location of the plants of Capsella bursa-pastoris collected in this study.

TABLA I. Localidades y ubicación geográfica de las plantas de Capsella bursa-pastoris colectadas en este estudio.

\begin{tabular}{|c|c|c|c|}
\hline LOCALITY & \multicolumn{2}{|c|}{ COORdinATES } & No. OF PLANTS \\
\hline Vallenar & $28^{\circ} 35^{\prime} 00,0^{\prime \prime} \mathrm{S}$ & $70^{\circ} 46^{\prime} 00,0^{\prime \prime} \mathrm{W}$ & 7 \\
\hline La Serena & $29^{\circ} 54^{\prime} 00,0^{\prime \prime} \mathrm{S}$ & $71^{\circ} 20^{\prime} 00,0 ” \mathrm{~W}$ & 12 \\
\hline Los Vilos & $31^{\circ} 54^{\prime} 37,3^{\prime \prime} \mathrm{S}$ & $71^{\circ} 30^{\prime} 02,7^{\prime \prime} \mathrm{W}$ & 9 \\
\hline San Felipe & $32^{\circ} 45^{\prime} 00,0^{\prime \prime} \mathrm{S}$ & $70^{\circ} 43^{\prime} 00,0$ " W & 14 \\
\hline Los Andes & $32^{\circ} 49^{\prime} 46,9^{\prime \prime} \mathrm{S}$ & $70^{\circ} 35^{\prime} 58,0$ " W & 21 \\
\hline Santiago & $33^{\circ} 26^{\prime} 45,6^{\prime \prime} \mathrm{S}$ & $70^{\circ} 41^{\prime} 18,2$ ' W & 35 \\
\hline Curicó & $34^{\circ} 58^{\prime} 47,6^{\prime \prime} \mathrm{S}$ & $71^{\circ} 14^{\prime} 48,3$ " W & 25 \\
\hline Talca & $35^{\circ} 25^{\prime} 49,9^{\prime \prime} \mathrm{S}$ & $71^{\circ} 38^{\prime} 23,5^{\prime \prime} \mathrm{W}$ & 24 \\
\hline Chillán & $36^{\circ} 07^{\prime} 49,0^{\prime \prime} \mathrm{S}$ & $71^{\circ} 50^{\prime} 27,0^{\prime \prime} \mathrm{W}$ & 27 \\
\hline Concepción & $36^{\circ} 49^{\prime} 17,3 ” \mathrm{~S}$ & $73^{\circ} 02^{\prime} 30,1^{\prime \prime} \mathrm{W}$ & 35 \\
\hline Los Ángeles & $37^{\circ} 27^{\prime} 05,8^{\prime \prime} \mathrm{S}$ & $72^{\circ} 20^{\prime} 20,6^{\prime \prime} \mathrm{W}$ & 36 \\
\hline Temuco & $38^{\circ} 43^{\prime} 44,9 ” \mathrm{~S}$ & $72^{\circ} 34^{\prime} 13,0^{\prime \prime} \mathrm{W}$ & 19 \\
\hline Chile Chico & $46^{\circ} 32^{\prime} 25,0^{\prime \prime} \mathrm{S}$ & $71^{\circ} 43^{\prime} 20,0^{\prime \prime} \mathrm{W}$ & 6 \\
\hline Punta Arenas & $53^{\circ} 09^{\prime} 45,0^{\prime \prime} \mathrm{S}$ & $70^{\circ} 55^{\prime} 21,0 ” \mathrm{~W}$ & 16 \\
\hline Total & & & 286 \\
\hline
\end{tabular}


were added, incubating at $37^{\circ} \mathrm{C}$ during $40 \mathrm{~min}$. An organic extraction was carried out with chloroform:isoamyl alcohol (24:1) with centrifugation by $10 \mathrm{~min}$. The aqueous phase was recovered; $3 \mathrm{M}$ sodium acetate, $\mathrm{pH} 5.2$, in an amount equivalent to $1 / 10$ of the recovered volume, and 2 volumes of cold absolute ethanol were added, and the DNA was allowed to precipitate at $-20^{\circ} \mathrm{C}$ for $6 \mathrm{~h}$. The pellet was then recovered by centrifugation and it was resuspended in 400 $\mu \mathrm{l}$ of $1 \mathrm{X}$ TE high salinity buffer $[0.01 \mathrm{M}$ Tris-HCl, 0.001 $\mathrm{M}$ EDTA, $1 \mathrm{M} \mathrm{NaCl}, \mathrm{pH}$ 8.0]. Then $40 \mu \mathrm{l}$ of $3 \mathrm{M}$ sodium acetate and $880 \mu \mathrm{l}$ of cold absolute ethanol were added, the mixture was allowed to precipitate, and the DNA obtained was re-suspended in $50 \mu \mathrm{l}$ of $1 \mathrm{X}$ TE buffer $\mathrm{pH} 8.0[0.01 \mathrm{M}$ Tris-HCl; 0.001 M EDTA, pH 8.0].

The amplifications were made according to the procedure described by Provan (2000) and Ceplitis et al. (2005): on $10-\mu 1$ volume that contained Taq DNA polymerase $1 \mathrm{X}$ buffer (Taq DNA recombinant polymerase, Fermentas), 1.5 $\mathrm{mM} \mathrm{MgCl}, 0.2 \mathrm{mM}$ dNTP (Fermentas), 0.3 U Taq DNA polymerase (Taq DNA recombinant polymerase, Fermentas), 10 pmol of each primer, and 20 - 50 ng of genomic DNA. The amplification profile consisted of an initial denaturation by 3 -min at $94{ }^{\circ} \mathrm{C}, 30$ cycles of $30 \mathrm{~s}$ at $94^{\circ} \mathrm{C}, 30 \mathrm{~s}$ at TAnn for each primer, $30 \mathrm{~s}$ at $72{ }^{\circ} \mathrm{C}$; and a final extension of $5 \mathrm{~min}$ at $72^{\circ} \mathrm{C}$. The alignment temperatures were adjusted for each pair of primer separately in order to improve the specificity of the PCR. The reaction was carried out using a TechneTc-312 thermocycler. The amplification products were resolved electrophoretically in an acrylamide denaturing gel $18 \% \mathrm{~T} 5 \%$ CBIS, in $1 \mathrm{X}$ TBE buffer solution [90 mM Tris, $90 \mathrm{mM}$ boric acid, $2 \mathrm{mM}$ EDTA] (Cregan \& Quigley 1997), mounted on the vertical electrophoresis sequencing system (Life Technologies S2001), coupled with a power supply (Biorad Powerpac 3000). The electrophoresis was performed at $1.500 \mathrm{~V}-50.000 \mathrm{Vh}$. The gel was then stained with silver nitrate to visualize the amplification products.

Finally, the size of the alleles observed by denaturing electrophoresis was estimated per calibration curves with respect to the band migration pattern of the molecular size standard (O'RangeRuler $10 \mathrm{bp}$, Fermentas). It is important to note that the size of the three loci amplified in this study were consistent with the size reported by the sequences deposited in GenBank under accession numbers DQ144475DQ144500.

TABLE II. Locus and primers for markers of cpDNA of C. bursa-pastoris, used in this study.

TABLA II. Locus y partidores para los marcadores de cpDNA of C. bursa-pastoris, usados en este estudio.

\begin{tabular}{cl}
\hline $\begin{array}{l}\text { Locus/ } \\
\text { primers }\end{array}$ & $\begin{array}{l}\text { Sequence } \\
\left(5^{\prime}-3^{\prime}\right)\end{array}$ \\
\hline ATCP31017 & \\
III & GCC TAC CGC ATC GAA ATA GA \\
CAA GAA AGT CGG CCA GAA TC \\
ATCP46615 & \\
$\operatorname{trnT(UGU)}$ & AAT TTT TTT CCA TTG CAC ATT G \\
$\operatorname{trnL(UAA)}$ & TCA GAA ATA GTC GAA CGG TCG \\
ATCP66701 & \\
$\operatorname{trnP(UGG)}$ & TCC ACA TCC TCC TTC TTT TTT \\
psaJ & CAT TTG AAA ACG TAA AGG CC \\
\hline
\end{tabular}

TABLE III. Molecular sizes (pb) estimated for the studied loci.

TABLA III. Tamaño molecular (pb) estimado para los loci estudiados

\begin{tabular}{lcc}
\hline Locus & $\begin{array}{c}\text { No. of observed } \\
\text { alleles }\end{array}$ & Observed size $(\mathrm{pb})$ \\
\hline ATCP46615 & 1 & $62 \pm 1(\mathrm{n}=168)$ \\
ATCP66701 & 1 & $102 \pm 2(\mathrm{n}=171)$ \\
ATCP31017 & 2 & $111 \pm 2($ haplotype A) $(\mathrm{n}=155)$ \\
& & $115 \pm 1$ (haplotype B) $(\mathrm{n}=13)$ \\
\hline
\end{tabular}




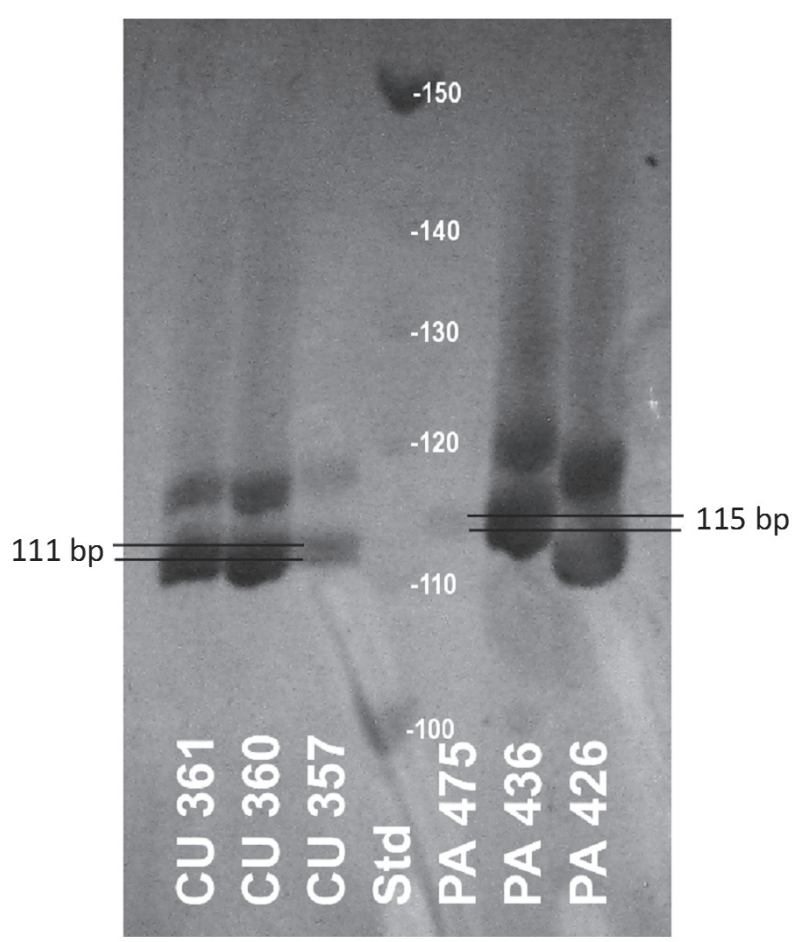

FIGURE 1. Electrophoresis of cpSSR locus for the ATCP31017 marker. CU: Curicó; PA: Punta Arenas; Std: ladder.

FIGURA 1. Electroforesis del locus cpSSR para el marcador ATCP31017. CU: Curicó; PA: Punta Arenas; Std: estándar.

\section{RESULTS}

The locus ATCP46615 of C. bursa-pastoris was amplified only in 168 of the 286 specimens $(58.7 \%)$, showed a single haplotype with a size estimated at $62 \mathrm{pb}$ (Table III). Similarly, the locus ATCP66701 was amplified in 171 plants (59.8\%) showed no haplotype variation; the estimated size of this locus was $102 \mathrm{pb}$ (Table III). In contrast, locus ATCP31017 was amplified in 168 plants (58.0\%; Table III), showing two alleles, one of $111 \mathrm{bp}$ (haplotype A) and other of $115 \mathrm{bp}$ (haplotype B) (Fig. 1; Table III). Haplotype A was found along continental Chile with a frequency equal to $100 \%$ in 13 of the 14 sampled localities (Fig. 2); the exception was Punta Arenas where haplotype A was represented in 18.8\% of the analyzed plants. Whereas, haplotype B was found only in plants from Punta Arenas (Fig. 2) in 13 of the 16 plants analyzed (i.e., 81.2\%; Fig. 2).

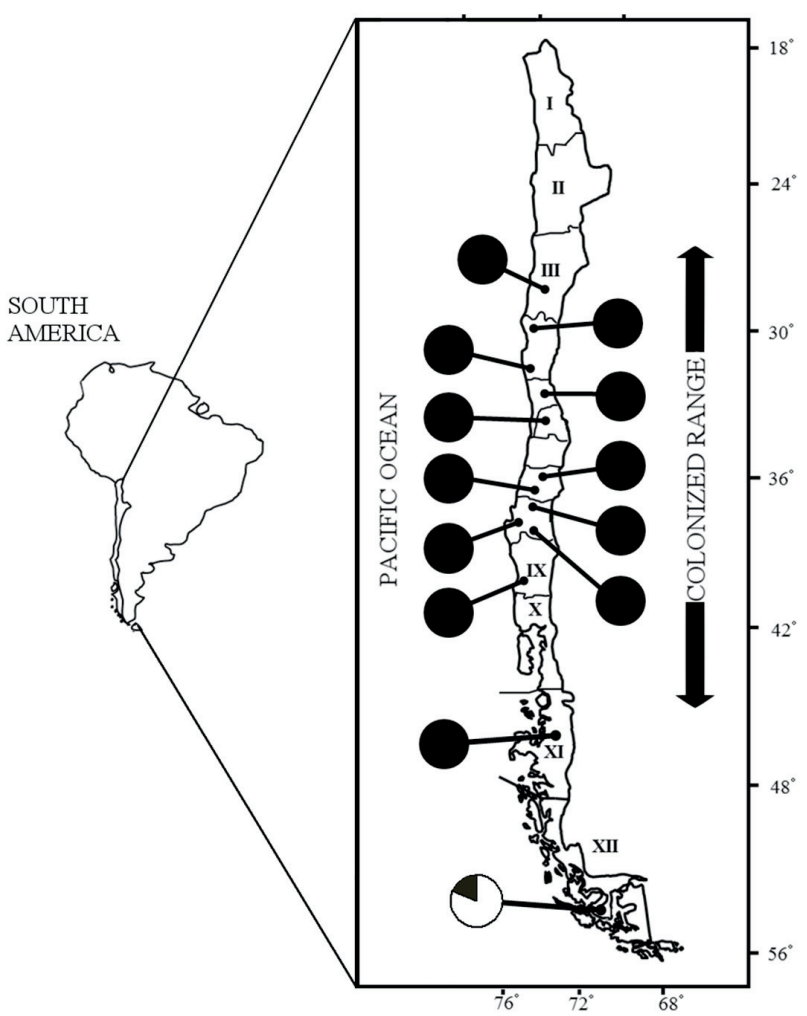

FIGURE 2. Geographic distribution of haplotypes identified for locus ATCP31017 (i.e. haplotipes A and B). The distribution and representation of both haplotypes on the sampled localities are showed as pie charts (filled pie for haplotipe A; open pie for haplotipe B).

FIGURA 2. Distribución geográfica de los haplotipos identificados para el locus ATCP31017 (i.e. haplotipos A y B). La distribución y representación de ambos haplotipos en las localidades de recolección es ilustrada en gráfico circular, donde el área ennegrecida representa al haplotipo A y blanco al haplotipo B.

\section{DISCUSSION}

Our results show that for the populations of C. bursapastoris in Chile, the ATCP46615 and ATCP66701 loci are monomorphic because exhibit only a single common haplotype in all analyzed samples, whereas locus ATCP31017 showed two haplotypes, A and B. The geographic distribution of these haplotypes showed a well defined geographical pattern, because haplotype B was present only in Punta Arenas (Southernmost Chile), whereas haplotype A was obtained from all continental Chile, including Punta Arenas. The reduced genetic diversity recorded in populations of $C$. bursa-pastoris in Chile could result from effects of genetic drift occurring upon small populations recently introduced in a new range (Avise 2000, Cox 2004, Dlugosch \& Parker 2008).

At least two hypotheses can explain the distributional 
pattern shown by locus ATCP31017. On the one hand, it could be argued that one of them (haplotype B) arose in Chile by mutation from the other previously introduced (probably the haplotype A). We believe that this is improbable because it has been stated that the evolutionary rate $(\mu)$ for these markers is too low, because it varies between $2.5 \times 10^{-5}$ and $2.9 \times 10^{-4}$ mutations per locus per generation (Cregan \& Quigley 1997, Provan et al. 1999, 2001, Ceplitis et al. 2005). This would imply, assuming a single mutation event, an introduction time for C. bursa-pastoris longer than 500 years, which is clearly an erroneous estimate.

A second hypothesis states that the presence of these haplotypes in C. bursa-pastoris may be the result of the history of the introduction of the species into the territory (Neuffer et al. 1999, Neuffer \& Hurka 1999). So, the widely distributed haplotype A can be explained at least by one event of introduction, probably associated with the Iberian colonization occurred since the 16th century, as has been suggested by Neuffer et al. (1999) and Ceplitis et al. (2005). The restricted distribution of the haplotype B suggests that this may have arrived from another introduction event. Evidence from allozymes and RAPD fragments related to Patagonian populations of C. bursapastoris with England populations (Neuffer et al. 1999, Ceplitis et al. 2005). According to Neuffer et al. (1999), Neuffer \& Hoffrogge (2000) and Neuffer et al. (2011), this pattern would be consequence of a second point of introduction led by English colonizers on Argentinian and Chilean Patagonia.

In the absence of a comprehensive botanical record, the spatial analysis of variation of molecular markers is a tool to infer possible spread dynamics for invasive species (Cox 2004). Thus, C. bursa-pastoris is particularly interesting because its global distribution and ability to colonize contrasting environments. In this line, future investigation can to advance upon the recognition of haplotypes of C. bursa-pastoris that exhibit differential invasibility, in order to prevent or control the introduction or/and spread of more "aggressive" or detrimental ones. Although more research is needed to clarify the dynamics invasive of C. bursa-pastoris in Chile, our results based on the analysis of haplotypes of cpSSR would support -but do no demonstrate- the proposal of Neuffer et al. (1999).

In summary, our results show that the populations of C. bursa-pastoris distributed in continental Chile offer genetic variability of one of the cpSSR markers analyzed. This variation indicates the presence of two cpDNA haplotypes. The present geographical distribution of these haplotypes supports the hypothesis that states that the introduction of C. bursa-pastoris in continental Chile at least came from two separated introduction.

\section{AKNOWLEDGEMENTS}

Financial support of different stages of this research by FONDECYT projects 11085013 (2008) and 3060015 (2006), by DICYT project 2081087, and by Línea 6 of the Proyecto Basal Centro para el Desarrollo de la Nanociencia y Nanotecnología (CEDENNA) of the Universidad de Santiago de Chile. J.A. Figueroa was partially supported by an intern project of Universidad Central.

\section{REFERENCES}

Allen, G.C., M.A. Flores-Vergara, S. Krasynanski, S. Kumar \& W.F. Thompson. 2006. A modified protocol for rapid DNA isolation from plant tissues using cetyltrimethylammonium bromide. Nature Protocols 1: 2320-2325.

Avise, J.C. 2000. Phylogeography: the history and formation of species. Cambridge, MA: Harvard University Press. 447 pp.

Castro, S.A., J.A. Figueroa, M. Muñoz-Schick \& F.M. Jaksic. 2005. Minimum residence time, biogeographical origin, and life cycle as determinants of the geographical extent of naturalized plants in continental Chile. Diversity and Distributions 11: 183-191.

Ceplitis, A., Y. Su \& M. Lascoux. 2005. Bayesian inference of evolutionary history from chloroplast microsatellites in the cosmopolitan weed Capsella bursa-pastoris (Brassicaceae). Molecular Ecology 14: 4221-4233.

Cox, G.W. 2004. Alien species and evolution. Island Press, Washington, DC. 377 pp.

Cregan, P.B. \& C.V. Quigley. 1997. Simple sequence repeat DNA marker analysis. In: G. Caetano-Anollés \& P.M. Gresshoff (eds.), DNA markers: Protocols, applications and overviews, pp. 177-180. Wiley-VCH, New York, USA.

Dlugosch, K.M. \& I.M. Parker. 2008. Founding events in species invasions: genetic variation, adaptive evolution, and the role of multiple introductions Molecular Ecology 17: 431449.

Doyle, J.J. \& J.K. Doyle. 1990. A rapid total DNA preparation procedure for fresh plant tissue. Focus 12: 13-15.

Figueroa, J.A., S.A. Castro, P.A. Marquet \& F.M. Jaksic. 2004. Exotic plant invasions to the Mediterranean region of Chile: causes, history and impacts. Revista Chilena de Historia Natural 77: 465-483.

Fuentes, N., A. Pauchard, P. Sánchez, J. Esquivel \& A. Marticorena. 2012. A new comprehensive database of alien plant species in Chile based on herbarium records. Biological Invasions 15: 847-858.

GAY, C. 1845. Historia física y política de Chile, Tomo I. Primera edición. París. pp. 172-173.

Hintz, M., C. Bartholmes, P. Nutt, J. Ziermann, S. Hameister, B. Neuffer \& G. Theissen. 2006. Catching a 'hopeful monster': shepherd's purse (Capsella bursa-pastoris) as a model system to study the evolution of flower development. Journal of Experimental Botany 57: 3531-3542.

Hurka, H. \& B. Neuffer. 1997. Evolution processes in the genus Capsella (Brassicaceae). Plant Systematics and Evolution 
206: 295-316.

Matthei, O., C. Marticorena, M. Quezada \& R. Rodríguez. 1995. Manual de las malezas que crecen en Chile. Edición Universidad de Chile, Santiago, Chile. 545 pp.

Neuffer, B. \& H. Hurka. 1999. Colonization history and introduction dynamics of Capsella bursa-pastoris (Brassicaceae) in North America: isozymes and quantitative traits. Molecular Ecology 8: 1667-1681.

Neuffer, B. \& R. Hoffrogge. 2000. Ecotypic and allozyme variation of Capsella bursa-pastoris and Capsella rubella (Brassicaceae) along latitude and altitude gradients on the Iberian Peninsula. Anales del Jardín Botánico de Madrid 57: 299-315.

Neuffer, B., K. Bernhardt, H. Hurka \& M. Kropf. 2011. Monitoring population and gene pool dynamics of the annual species Capsella bursa-pastoris (Brassicaceae): a review of relevant species traits and the initiation of a long-term genetic monitoring programme. Biodiversity and Conservation 20: 309-323.

Neuffer, B., S. Hirschle \& S. JÄger. 1999. The colonizing history of Capsella in Patagonia (South America): molecular and adaptive significance. Folia Geobotanica 34: 435-450.
Newton, C.R., A. Graham, L.E. Heptinstall, S.J. Powell, C. Summers, N. Kalsheker, J.C. Smith \& A.F. Markham. 1989. Analysis of any point mutation in DNA. The amplification refractory mutation system (ARMS). Nucleic Acids Research 17: 2503-2516.

Provan, J. 2000. Novel chloroplast microsatellites reveal cytoplasmic variation in Arabidopsis thaliana. Molecular Ecology 9: 2183-2185.

Provan, J., N. Soranzo, N.J. Wilson, D.B. Goldstein \& W. Powell. 1999. A low mutation rate for chloroplast microsatellites. Genetics 153: 943-947.

Provan, J., W. Powell \& P.M. Hollingsworth. 2001. Chloroplast microsatellites: new tools for studies in plant ecology and evolution. Trends in Ecology \& Evolution 16: 142-147.

RANDALl, R.P. 2002. A Global Compendium of Weeds. R.G. \& F.J., Richardson, Melbourne, Victoria, Australia. 906 pp.

Saltonstall, K. 2002. Cryptic invasion by a non-native genotype of the common reed, Phragmites australis, into North America. Proceedings of the National Academy of Sciences 99: 2445-2449.

ZızKA, G. 1991. Flowering plants of Easter Island. Frankfurt: Palmengarten. 108 pp.

Recibido: 11.09 .13

Aceptado: 17.06.14 